\title{
ANALISIS RASIO
}
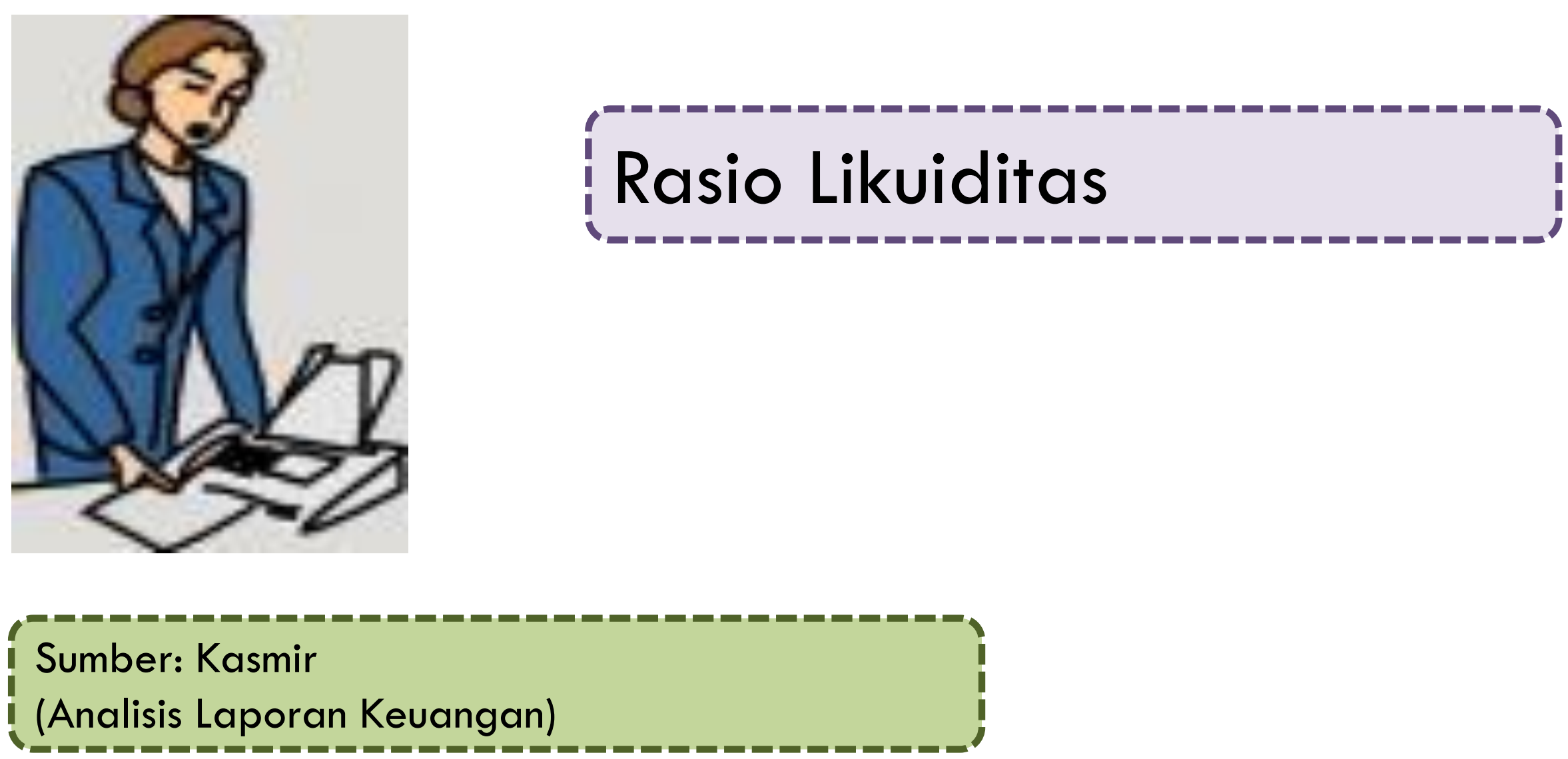

Gina Septiana,SE.,M.Si 


\section{PENGERITAN}

\section{Fred Weston}

Rasio likuiditas merupakan rasio yang menggambarkan kemampuan perusahaan dalam memenuhi kewajiban (utang jangka pendek. Artinya apabila perusahaan ditagih, perusahaan akan mampu untuk memenuhi utang tersebut terutama utang yang sudah jatuh tempo.

Fungsi rasio likuiditas berfungsi untuk menunjukkan atau mengukur kemampuan perusahaan dalam memenuhi kewajibannya yang sudah jatuh tempo baik kewajiban kepada pihak luar perusahaan (likuiditas badan usaha) maupun di dalam perusahaan (likuiditas perusahaan). 


\section{PENGERTLAN}

Rasio likuiditas atau sering disebut rasio modal kerja merupakan rasio yang digunakan untuk mengukur seberapa likuidnya suatu perusahaan. Caranya adalah dengan membandingkan seluruh komponen yang ada di aktiva lancar dengan komponen di passiva lancar (utang jangka pendek) 


\section{TUJUAN DAN MANF AT RASIO LIKUIDITAS}

1. Untuk mengukur kemampuan perusahaan membiayai kewajiban atau utang yang segera jatuh tempo pada saat di tagih.

2. Untuk mengukur kemampuan perusahaan membiayai kewajiban jangka pendek dengan aktiva lancar secara keseluruhan

3. Untuk mengukur kemampuan perusahaan membayar kewajiban jangka pendek dengan aktiva lancar tanpa memperhitungkan sediaan atau piutang

4. Untuk mengukur atau membandingkan antara jumlah sediaan yang ada dengan modal kerja perusahaan

5. Untuk mengukur seberapa besar uang kas yang tersedia untuk membayar utang 


\section{CONT,}

6. Sebagai alat perencanaan ke depan, terutama yang berkaitan dengan perencanaan kas dan utang

7. Untuk melihat kondisi dan posisi likuiditas perusahaan dari waktu ke waktu dengan membandingkannya untuk beberapa periode

8. Untuk melihat kelemahan perusahaan dari masing-masing komponen yang ada di aktiva lancar dan utang lancar

9. Menjadi alat pemicu bagi pihak manajemen untuk memperbaiki kinerjanya 


\section{JENIS-JENIS RASIO LIKUIDIT AS}

1. Rasio lancar (current ratio)

2. Rasio cepat (quick ratio)

3. Rasio kas (cash ratio)

4. Rasio perputaran kas (cash turn over

5. Inventory to net working capital 


\section{RASIO LANCAR (CURRENT RATIO)}

\section{Pengertian}

Rasio lancar atau current ratio merupakan rasio untuk mengukur kemampuan perusahaan dalam membayar kewajiban jangka pendek atau utang yang segera jatuh tempo pada saat ditagih secara keseluruhan. Dengan kata lain seberapa banyak aktiva lancar yang tersedia untuk menutupi kewajiban jangka pendek yang segera jatuh tempo. Rasio ini juga sebagai bentuk untuk mengukur tingkat keamanan (margin of safety) perusahaan.

Perhitungan rasio lancar :

Current Ratio $=\frac{\text { Aktiva Lancar }(\text { Current Assets })}{\text { Utang Lancar }(\text { Current Liabilities })}$ 


\section{RASIO LANCAR (CURRENT RATIO)}

\section{Aktiva Lancar (Current Assets)}

Merupakan harta perusahaan yang dapat dijadikan uang dalam waktu singkat (maksimal satu tahun). Komponen aktiva lancar yaitu kas, piutang, sediaan, biaya dibayar di muka, pendapatan yang masih harus diterima dan aktiva lancar lainya.

\section{Utang Lancar (Current Liabilities)}

Merupakan kewajiban perusahaan jangka pendek (maksimal satu tahun), artinya utang ini segera harus dilunasi dalam waktu paling lama satu tahun. Komponen utang lancar terdiri atas utang dagang, utang bank satu tahun, utang wesel, utang gaji, utang pajak, utang dividen serta utang jangka pendek lainnya. 


\section{HASIL PENGUKURAN RASIO}

Ada dua hasil pengukuran rasio yaitu :

1. Apabila perusahaan mampu memenuhi kewajibannya, dikatakan perusahaan tersebut likuid

2. Apabila perusahaan tidak mampu memenuhi kewajiban tersebu atau tidak mampu dikatakan inlikuid

Alasanya :

Hal ini dapat saja terjadi karena kas tidak digunakan sebaik mungkin. Untuk mengatakan suatu kondisi perusahaan baik atau tidaknya, ada suatu standar rasio yang digunakan misalnya ratarata industri untuk usaha yang sejenis atau dapat pula digunakan target yang telah ditetapkan perusahaan sebelumnya. 


\section{CONTOH PENGUKURAN RASIO}

Jika suatu perusahaan memiliki utang yang segera jatuh tempo senilai Rp 1.000.000, sementara aktiva lancar yang dimiliki perusahaan sebesar Rp 1.200 .000 perusahaan ini dikatakan likuid. Artinya mampu membayar utang tersebut, sebaliknya jika aktiva lancar yang dimiliki perusahaan hanya sebesar Rp 800.000, perusahaan dikatakan inlikuid artinya perusahaan tidak mampu membayar utang dengan seluruh aktiva lancar yang dimilikinya. 


\section{CONTOH PERHITUNGAN RASIO}

Untuk pembahasan rasio-rasio menggunakan laporan keuangan PT Yumiko Maharani, Tbk 


\section{CONTOH PERHITUNGAN RASIO}

\section{\begin{tabular}{l|l|l|} 
Komponen Laporan Keuangan & 2005 & 2006
\end{tabular}}

\begin{tabular}{|l|r|r|}
\hline Total Aktiva Lancar (current assets) & 1.640 & 1.340 \\
\hline
\end{tabular}

\begin{tabular}{|l|r|r|}
\hline Total Hutang Lancar (current liabilities) & 750 & 750
\end{tabular}

Untuk tahun 2005

Current Ratio $=\frac{1.640}{750}$

$=2,18$ kali (dibulatkan 2,2 kali)

Artinya :

Jumlah aktiva lancar sebanyak 2,2 kali utang lancar, atau setiap 1 Rupiah utang lancar dijamin oleh 2,2 rupiah harta lancarnatau 2,2 : 1 antara aktiva lancardengan utang lancar.

Untuk tahun 2006????? 


\section{HASIL PENGUKURAN RASIO}

\section{Untuk tahun 2006}

Current Ratio $=\frac{1.340}{750}$

$=1,8$ kali

Artinya :

Jumlah aktiva lancar sebanyak 1,8 kali utang lancar, atau setiap 1 Rupiah utang lancar dijamin oleh 1,8 rupiah harta lancar atau 1,8:1 antara aktiva lancardengan utang lancar.

Kesimpulan :

Jika rata-rata indusri untuk current ratio adalah dua kali keadaan perusahaan untuk tahun 2005 berada dalam kondisi baik mengingat rasionya di atas rata-rata industri. Namun untuk tahun 2006 kondisnya kurang baik jika dibandingkan dengan perusahaan lainnya masih di bawah rata-rata industri. 


\section{RASIO CEPAT (QUICK RATIO)}

\section{Pengertian}

Merupakan rasio yang menunjukkan kemampuan perusahaan dalam memenuhi atau membayar kewajiban atau utang lancar dengan aktiva lancar tanpa memperhitungkan nilai sediaan. Artinya nilai sediaan diabaikan dengan cara dikurangi dari nilai total aktiva lancar karena sediaan dianggap memerlukan waktu relatif lebih lama untuk diuangkan, apabila perusahaan membutuhkan dana cepat untuk membayar kewajibannya dibandingkan dengan aktiva lancar lainnya.

Perhitungan

Quick Ratio $=\frac{\text { Current Assets }- \text { Inventory }}{\text { Current Liabilities }}$ 


\section{CONTOH PERHITUNGAN RASIO}

\section{\begin{tabular}{ll|l|l|}
\hline Komponen Laporan Keuangan & 2005 & 2006
\end{tabular}}

\begin{tabular}{|l|r|r|}
\hline Total Aktiva Lancar (current assets) & 1.640 & 1.340 \\
\hline
\end{tabular}

\begin{tabular}{|l|r|r|}
\hline Total Hutang Lancar (current liabilities) & 750 & 750 \\
\hline
\end{tabular}

\begin{tabular}{|l|l|l} 
Sediaan (inventory) & 250 & 310
\end{tabular}

Untuk tahun 2005

Quick Ratio $=\frac{1.640-250}{750}$

$=2,52$ kali

Untuk tahun 2006

Quick Ratio $=\frac{1.340-310}{750}$

$=2,20$ kali 


\section{KESIMPULAN PERHITUNGAN RASIO}

\section{Kesimpulan}

Jika rata-rata industri untuk quick ratio adalah 1,5, maka keadaan perusahaan lebih baik dari perusahaan lain. Kondisi ini menunjukkan bahwa perusahaan tidak harus menjual sediaan bila hendak melunasi utang lancar, tetapi dapat menjual surat berharga atau penagihan piutang.

Jika rasio perusahaan di bawah rata-rata industri, keadaan perusahaan lebih buruk dari perusahaan lainnya. Hal ini menyebabkan perusahaan harus menjual sediaanya untuk melunasi pembayaran utang lancar, padahal menjual sediaan untuk harga yang normal relatif sulit, kecuali perusahaan menjual di bawah harga pasar yang tentunya bagi perusahaan jelas menambah kerugian. 


\section{RASIO KAS (CASH RATIO)}

\section{Pengertian}

Merupakan alat yang digunakan untuk mengukur seberapa besar uang kas yang tersedia untuk membayar utang. Ketersediaan uang kas dapat ditunjukkan dari tersediaanya dana kas atau setara dengan kas seperti : rekening giro atau tabungan di bank (yang dapat ditarik setiap saat).

Rumus cash ratio

Cash ratio $=\frac{\text { Cash or cas equivalent }}{\text { Current Liabilities }}$

Atau

Cash ratio $=\frac{\text { Kas }+ \text { Bank }}{\text { Current Liabilities }}$ 


\section{CONTOH PERHITUNG AN RASIO}

\begin{tabular}{|c|c|c|}
\hline Komponen Laporan Keuangan & 2005 & 2006 \\
\hline Total Aktiva Lancar (current assets) & 1.640 & 1.340 \\
\hline Total Hutang Lancar (current liabilities) & 750 & 750 \\
\hline Kas & 250 & 260 \\
\hline Giro & 350 & 300 \\
\hline
\end{tabular}

Untuk tahun 2005

Cash Ratio $=\frac{250+350}{750}$

$=0,8$ atau $80 \%$

Untuk tahun 2006????? 


\section{CONTOH PERHITUNGAN RASIO}

$$
\begin{aligned}
\text { Cash Ratio } & =\frac{260+300}{750} \\
& =0,746 \text { atau } 75 \%
\end{aligned}
$$

\section{Kesimpulan}

Jika rata-rata industri untuk cash ratio adalah 50\%, maka keadaan perusahaan lebih baik dari perusahaan lain. Namun kondisi rasio kas terlalu tinggi juga kurang baik karena ada dana yang menganggur atau yang tidak atau belum digunakan secara optimal. Sebaliknya apabila rasio kas di bawah rata-rata industri, kondisi kurang baik ditinjau dari rasio kas karena untuk membayar kewajiban masih memerlukan waktu untuk menjual sebagian dari aktiva lancar lainnya. 


\section{RASIO PERPUTARAN KAS}

\section{Pengertian}

Berfungsi untuk mengukur tingkat kecukupan modal kerja perusahaan yang dibutuhkan untuk membayar tagihan dan membiayai penjualan. Artinya rasio ini digunakan untuk mengukur tingkat ketersediaan kas untuk membayar tagihan (utang) dan biayabiaya yang berkaitan dengan penjualan.

Hasil perhitungan rasio perputaran kas dapat diartikan sebagai berikut :

a. Apabila rasio perputaran kas tinggi berarti ketidakmampuan perusahaan dalam membayar tagihannya

b. Apabila rasio perputaran kas rendah, dapat diartikan kas yang tertanam pada aktiva yang sulit dicairkan dalam waktu singkat, sehingga perusahaan harus bekerja keras dengan kas yang lebih sedikit 


\section{CONTOH PERHITUNGAN RASIO}

Rasio perputaran kas $=\frac{\text { Penjualan bersih }}{\text { Modal ker ja bersih }}$

Modal kerja bersih = Aktiva lancar - Hutang Lancar

Contoh :

\begin{tabular}{|l|r|r|}
\hline \multicolumn{1}{|c|}{ Komponen Laporan Keuangan } & 2005 & \multicolumn{1}{c|}{2006} \\
\hline Penjualan bersih (net sales) & 5.950 & 5.550 \\
\hline Total aktiva lancar (current assets) & 1.640 & 1.340 \\
\hline Total Hutang Lancar (current liabilities) & 750 & 750 \\
\hline
\end{tabular}

Untuk tahun 2005

Rasio perputaran kas $=\frac{5.950}{(1.640-750)}$

$=6,68$ kali atau (dibulatkan 7 kali) 


\section{CONTOH PERHITUNG AN RASIO}

Untuk tahun 2006

Rasio perputaran kas $=\frac{5.550}{(1.340-750)}=9,4$ kali

\section{Kesimpulan :}

Jika rata-rata industri untuk perputaran kas adalah 10 kali, keadaan perusahaan pada tahun 2005 kurang baik karena masih cukup jauh dari rata-rata industri. Namun, kondisi tahun 2006 dikatakan baik karena kondisinya sama dengan rata-rata industri. 


\section{INVENTORY TO NET WORKING CAPITAL}

\section{Pengertian}

Merupakan rasio yang digunakan untuk mengukur atau membandingkan antara jumlah sediaan yang ada dengan modal kerja perusahaan. Modal kerja tersebut terdiri dari pengurangan antara aktiva lancar dengan utang lancar.

Rumus :

Inventory to NWC $=\frac{\text { Inventory }}{\text { (current assets -current liabilities) }}$

Contoh : 


\section{INVENTORY TO NET WORKING CAPITAL}

\section{Pengertian}

Merupakan rasio yang digunakan untuk mengukur atau membandingkan antara jumlah sediaan yang ada dengan modal kerja perusahaan. Modal kerja tersebut terdiri dari pengurangan antara aktiva lancar dengan utang lancar.

Rumus :

Inventory to NWC $=\frac{\text { Inventory }}{\text { (current assets -current liabilities) }}$

\section{Komponen Laporan Keuangan 20052006}

Total aktiva lancar (current assets)

$1.640 \quad 1.340$

Total Hutang Lancar (current liabilities)

$750 \quad 750$

Sediaan (inventory)

$250 \quad 310$




\section{INVENTORY TO NET WORKING CAPITAL}

\section{Untuk tahun 2005}

Inventory to NWC $=\frac{250}{(1.640-750)}$

$$
=0.105 \text { dibulatkan }(11 \%)
$$

\section{Untuk tahun 2006}

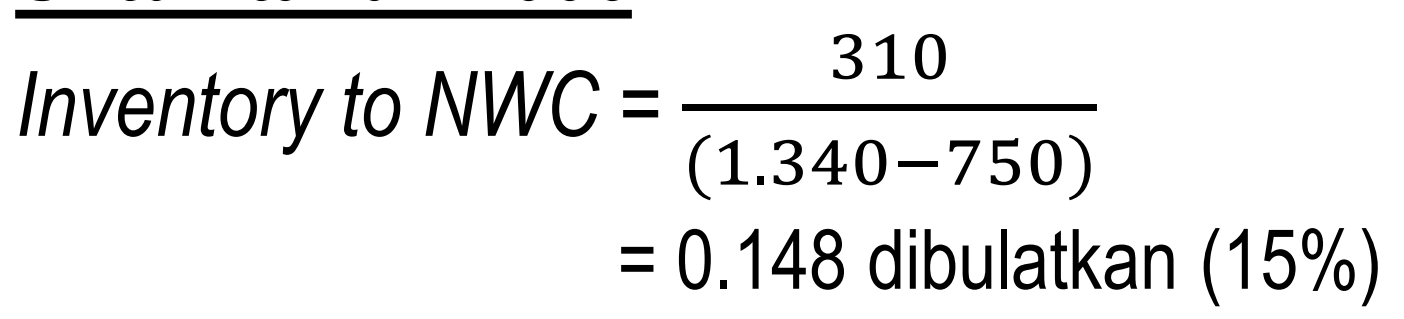

Kesimpulan :

Jika rata-rata industri inventory to NWC adalah $12 \%$, keadaan perusahaan pada tahun 2005 kurang baik karena masih di bawah rata-rata industri. Namun tidak terlalu buruk karena masih mendekati rata-rata industri, hanya saja masih perlu ditingkatkan. Untuk tahun 2006 kondisinya baik karena berada di atas rata-rata industri 


\section{HASIL PENGUKURAN}

Dari pengukuran rasio sebelumnya dapat dilihat kondisi dan posisi perusahaan seperti yang terlihat dalam tabel berikut ini :

\begin{tabular}{|l|c|c|c|}
\multicolumn{1}{|c|}{ Jenis rasio } & $\mathbf{2 0 0 5}$ & $\mathbf{2 0 0 6}$ & $\begin{array}{c}\text { Standar } \\
\text { Industri }\end{array}$ \\
\hline Current ratio & 2,2 kali & 1,8 kali & 2 kali \\
\hline Quick ratio & 2,5 kali & 2,2 kali & 1,5 kali \\
\hline Cash ratio & $80 \%$ & $75 \%$ & $50 \%$ \\
\hline Cash turn over & $7 \%$ & $10 \%$ & $10 \%$ \\
\hline Inventory to net working capital & $28 \%$ & $52 \%$ & $50 \%$ \\
\hline
\end{tabular}




\section{CONT,}

- Rasio lancar (current ratio) dapat dilihat terjadi penurunan sebanyak 2,2 kali. Hal ini dapat dikatakan memuaska karena berada di atas rata-rata industri, namun sebalikya pada tahun 2006 menjadi kurang memuaskan karena masih di bawah rata-rata industri

- Jika rata-rata industri untuk current ratio adalah dua kali, current ratio perusahaan tahun 2005 dikatakan baik. Namun, untuk tahun 2006 dikatakan kurang baik karena tidak memenuhi syarat standar rata-rata industri. Oleh karena itu, kondisi tahun 2006 perlu dikhawatirkan mengingat rasio lancar yang dimiliki perusahaan masih di bawah rata-rata industri dan perlu ditingkatkan lagi seperti tahun sebelumnya. Hal ini penting mengingat rasio yang menyamai rata-rata industri yang dibutuhkan guna menumbuhkan tingkat kepercayaan berbagai pihak kepada perusahaan. 


\section{CONT,",}

- Hasil rasio cepat (quick ratio) dari tahun 2005 ke tahun 2006 juga mengalami perubahan atau penurunan. Jika semula pada tahun 2005 rasio cepatnya 2,5 kali sedangkan tahun 2006 turun menjadi 2,2 kali

- Jika rata-rata industri untuk quick ratio adalah 1,5 kali, kondisi perusahaan dapat dikatakan cukup memuaskan untuk kedua tahun tersebut, walaupun terjadi penurunan.

- Hasil pengukuran rasio kas dari tahun 2005 ke tahun 2006 juga mengalami penurunan. Jika semula pada tahun 2005 rasio kas sebanyak $80 \%$ pada tahun 2006 turun menjadi $75 \%$

- Jika rata-rata industri rasio kas 50\%, perusahaan berada dalam keadaan memuaskan karena masih di atas rata-rata industri. Hanya saja perlu diantisipasi apakah penggunaan kas sudah dillakukan secara optimal karena rasio kas yang tinggi dicurigai 
karena manajemen belum melakukan pengelolaan secara baik, artinya adanya kas uang idle (menganggur) dan tentu saja ini dapat merugikan perusahaan.

- Hasil pengukuran rasio perputaran kas dari tahun 2005 ke tahun 2006 juga mengalami kenaikan. Jika semula pada tahun 2005 rasionya sebesar $7 \%$ pada tahun 2006 naik menjadi 10\%. Ini berarti perusahaan memiliki kemampuan yang lebih besar untuk menutupi biaya-biaya perusahaan.

- Jika rata-rata industri rasio perputaran kas 10\% kondisi perusahaan tahun 2005 tidak memuaskan karena masih di bawah rata-rata industri. Sementara itu, rasio untuk tahun 2006 memuaskan karena sama dengan rata-rata industri

- Hasil pengukuran inventory to net working capital dari tahun 2005 ke tahun 2006 mengalami kenaikan. Jika semula pada tahun 2005 


\section{CONT,",}

rasio kas sebanyak 1\% pada tahun 2006 naik menjadi 15\%

- Jika standar rata-rata industri inventory to net working capital 12\%, rasio perusahaan ini untuk tahun 2005 dinilai kurang baik meski tidak terlalu jauh dari rata-rata industri. Sementara itu untuk tahun 2006 baik, karena diatas rata-rata industri 


\section{Pengertian}

Risiko likuiditas merupakan bentuk risiko yang dialami oleh suatu perusahaan karena ketidakmampuannya dalam memenuhi kewajiban jangka pendeknya, sehingga memberi pengaruh kepada ternganggunya aktivitas perusahaan ke posisi tidak berjalan secara normal.

Sebab terjadinya risiko likuiditas

- Utang perusahaan yang berada di posisi extreme leverage, artinya utang perusahaan sudah berada dalam kategori yang membahayakan perusahaan itu sendiri.

- Jumlah hutang dan berbagai tagihan yang datang pada saat jatuh tempo seudah begitu besar.

- Perusahaan telah melakukan kebijakan strategi yang salah sehingga berpengaruh kerugian jangka pendek dan panjang. 


\section{RISIKO LIKUIDITAS}

Sebab terjadinya risiko likuiditas (lanjutan)

- Kepemilikan aset perusahaan yang tidak lagi mencukupi untuk menstabilkan perusahaan yaitu sudah terlalu banyak aset yang dijual, sehingga jika aset tersebut masih ingin dijual maka itu juga tidak mencukupi untuk menstabilkan perusahaan.

- HIm 165 